\title{
The Balanced Scorecard Approach as a Tool for Performance Evaluation in the Hospitality Industry
}

\author{
Ghada Mohamed Khairat \\ Tourism Studies Department, Faculty of Tourism \& Hotels, University of Sadat City
}

\begin{abstract}
Nowadays, hotel organizations endeavor to achieve long-term competitive advantage in the marketplace through the implementation of strategic performance measurement systems. The traditional measure of hotel performance is the hotel's financial aspects, such as net profit, return on investment, return on assets, and earnings per share. However, such aspects have a serious limitation that they cannot recognize intangible factors. Therefore, professors Robert Kaplan and David Norton developed a strategic management tool called the Balanced Scorecard model (BSC). The BSC enables organizations to translate their mission, vision and strategy into a comprehensive set of performance measures and to provide the framework for strategic measurement and management, hoping that the Balanced Scorecard will supplement traditional financial measures with other three key business perspectives that could be used to measure performance: customers, internal business processes, and learning and growth. This paper aims at identifying the key performance indicators (KPI) in hospitality industry used for performance measurement. It also investigates BSC awareness and use within hotels. In addition, the research aims to discuss how hospitality establishments can reap benefits from implementing the BSC and shows how BSC has the potential to deliver competitive advantage. In order to achieve these goals, a model is developed based on the BSC perspectives. This model has been transformed into a questionnaire. The research sample includes mainly hotels' managers (Regional Managers, Assistant General Managers, and Department Managers). Results have revealed that many hospitality establishments already apply the BSC to measure their performance. Moreover, despite the fact that hotels' managers strongly support the potential usefulness of the BSC in their business, they still focus on traditional financial measures for measuring hotel performance. Furthermore, the results have showed that the customer attribute is considered the most important among the four given core attributes, followed by the financial perspective, internal business processes perspective, and learning and growth perspective, respectively. This indicates that hotels managements start to take into account other indicators to assess performance than financial dimension. Also, they find out that it is hard to measure performance when it only counts financial aspects due to the uniqueness of hotel products and services.
\end{abstract}

Keywords: Balanced Scorecard; Performance measurement; Performance management; Strategic management; Strategic maps; Hotels; Financial and non-financial measures; KPI.

\section{Introduction}

Performance measurement is an important managerial activity for hotels to deliver competitive advantage. ${ }^{1}$ Performance measurement is the process of quantifying past actions to facilitate the pursuit of organizational control. ${ }^{2,3}$ Traditional performance measurement systems, meanwhile, typically stress the shortterm and past orientation while largely ignore the drivers of future performance. ${ }^{4}$ Additionally, traditional operational metrics provide a picture of profitability in terms of efficiency, but they fail to provide a systematic depiction of effectiveness in terms of achievement of strategic objectives. ${ }^{5}$

Moreover, the traditional means of performance measurement are excessively profit based, unbalanced, unsatisfactory for businesses seeking a competitive advantage, ${ }^{1,6}$ lack market orientation, ${ }^{7}$ lack accuracy, ${ }^{8}$ and non-holistic; therefore; over-reliance on them is no longer relevant for today's managers. ${ }^{\mathbf{5}{ }^{\mathbf{9}} \text { Measuring }}$ organizational success and implementing effective strategies for success represent continuous challenges for managers. ${ }^{3}$ Whilst financial measures are clearly important, new frameworks have emerged in recent years that take into account a broader range of measures. These frameworks aim to respond to the criticisms leveled at 
financial measures. ${ }^{6}$ Performance measurement frameworks now need to move beyond the mere collection of financial and non-financial measures and seek to identify causal links among measures, strategies, and outcomes. ${ }^{5}$ The Balanced Scorecard model is one of a number of performance measurement and management tools used to execute strategy. The BSC implementation can be said to achieve success and popularity being pioneered in the hospitality industry by Hilton Hotels in 1994 and Marriott. ${ }^{7}$ The Balanced Scorecard is a valueadding system for management. ${ }^{\mathbf{1 0}}$ Also, a well-designed BSC can help management to translate the organization's mission and vision into goals, actions and performance measures, align individual and organizational goals, and measure/guide progress towards goal attainment. ${ }^{11}$ The usage of the Balanced Scorecard by hotel organizations is utterly low due to the lack of knowledge about such model. ${ }^{12}$ Recently, a growing number of academics have acknowledged the need for formal, systematic and large-scale evaluation of the effectiveness of the BSC. ${ }^{\mathbf{1 0}}$

\section{Performance Measurement}

Performance measurement has become increasingly important due to the changing nature of work, increasing competition, specific improvement initiatives, national and international quality awards, changing organizational roles, the power of technology, and changing external demand. ${ }^{\mathbf{1 3}}$

Organizations need to set clear goals and objectives, develop criteria for performance measurement, evaluate that performance, and compare the performance against the goals and objectives of the organization. Moreover, measuring performance plays an important role in planning and decision-making; it also makes the link between strategy, performance and strategic evaluation. Over the past few decades a variety of performance measurement approaches or frameworks have emerged to help guide managers in achieving better outcomes. ${ }^{9}$

${ }^{14}$ describes performance measurement as "a process of assessing progress towards achieving predetermined goals, including information on the efficiency by which resources are transformed into goods and services, the quality of those outputs and outcomes, and the effectiveness of organizational operations in terms of their specific contributions to organizational objectives." Performance measurement is also defined as "the systematic attempt to learn how responsive organization's products and services are to the needs of the customer and the organization's ability to improve effectiveness and efficiency in quantitative terms."15

Furthermore, ${ }^{16}$ considers performance measurement as "the process of quantifying the efficiency and effectiveness of past actions".While ${ }^{17}$ suggests that it is used for "evaluating how well organizations are managed and the value they deliver for customers and other stakeholders". Moreover, ${ }^{\mathbf{8}}$ mentioned that "performance measurement is the process of measuring work accomplishments and output, as well as measuring in-process parameters that affect work output and accomplishments."

On the other hand, performance management is defined as a formal process used to measure, evaluate, and influence job-related attitudes, behaviors, and performance results with employees.19Moreover, it is defined by 20as "a process which contributes to the effective management of individuals and teams in order to achieve high levels of organizational performance". However, performance management has been traditionally defined as the process of financial control,in which the mission and strategy are translated into budgets, and subsequently the results are compared with budgets. The need for more flexible and responsive organizations and valuable resource utilization as well as shrinking budgets, heavy price pressures, and concern for costs and delivery systems have created demands for effective performance measures.13, 21As a result, hospitality organizations have to deal with performance measures in different performance dimensions. There is a considerable degree of concern that despite the progress taking place with regard to the design of more effective performance measurement systems, hospitality organizations are still focusing on more traditional forms of performance measures which are narrow and easily quantifiable. 21

With the help of performance measurement tools, organizations can monitor the implementation of their business plans and strategies, thereby contributing to their organizational success. ${ }^{22}$ The role of performance measurement systems: (1) help the organization assess whether it is receiving the expected contributions from employees and suppliers; (2) help the organization evaluate whether it is giving each stakeholder group what it needs to continue their support so the organization can achieve its primary objectives; (3) assist the organization 
in implementing processes that contribute to achieving the strategic objectives; and (4) help the organization assesses and monitor strategic planning in accordance with the agreements negotiated with key stakeholders. ${ }^{\mathbf{2 3}}$

The key performance indicators (KPIs) for hotels are considered metrics for monitoring the qualitative or quantitative performance of strategic objectives, outcomes, or key result area (KRA). They are also absolutely critical to the success of an activity and growth of the organization overall. The purpose of hotel KPIs is to provide decision makers in the organization measurable indicators for measuring or judging the organizational performance and for measuring the achievements of organizational objectives. These Key Performance Indicators are represented in innovation, employee performance measures, the external environment, operational performance, financial measures, service quality, customer satisfaction, organizational learning, critical success factors, and competitive environment., ${ }^{94}$

\section{Balanced Scorecard Definitions}

The simplest way to refer to the BSC is as a tool with different blends: A comprehensive management and strategic tool. The BSC is being used as a measurement tool, performance management system, or strategic management and control system. ${ }^{25}$ The following definitions of the Balanced Scorecard concept present a rich picture from multiple angles:

- $\quad$ The Balanced Scorecard retains traditional financial measures. Financial measures tell the story of past events, an adequate story for industrial age companies for which investments in long-term capabilities and customer relationships are not critical for success. However, these financial measures are inadequate for guiding and evaluating the journey that information age companies must make to create future value through investment in customers, suppliers, employees, processes, technology, and innovation. ${ }^{\mathbf{2 6}}$

- The Balanced Scorecard is a tool that translates an organization's mission and strategy into a comprehensive set of performance measures that provide the framework for a strategic measurement and management system. ${ }^{27}$

- $\quad$ The Balanced Scorecard is a strategic planning and management system that is used extensively in business and industry, government, and nonprofit organizations worldwide to align business activities to the vision and strategy of the organization, improve internal and external communications, and monitor organization performance against strategic goals. ${ }^{28}$

- $\quad$ The Balanced Scorecard has multiple meanings. The initial meaning, when it was first popularized in the early 90s, was of an approach for generating a performance report through grouping performance measures via perspectives. The most commonly used perspectives are financial, customer, internal processes, and learning and growth. Gradually, this management tool has evolved to become the basis for a performance management system that uses strategic, operational and individual performance plans as the basis for a communicating, monitoring and improving organizational performance. ${ }^{29}$

This notion of different perspectives is unique to the Scorecard. Another important feature of the Scorecard is the clear link between corporate strategy and measures throughout the organization. Furthermore, by focusing on the four perspectives, managers can articulate their core vision, strategy, and goals before translating them into specific measures, targets, and initiatives. The Scorecard provides a link between strategy and operations. ${ }^{\mathbf{3 0}}$

\section{The Balanced Scorecard as a Performance Measurement System}

The Balanced Scorecard (BSC) is a tool to create a framework for a strategic measurement and management system, transforming an organization's mission and strategies into a comprehensive set of performance measurements. ${ }^{31}$ It was developed by Kaplan and Norton in 1992 to address the limitations of the use of the traditional financial performance measurement systems. The financial accounting measures that are generally used include the return on investment, the market share and the earnings per share, since these measures produce results by relying on past performances. In the competitive environment of nowadays this kind of information may be misleading and insufficient, especially in areas relating to the development and the innovation of the organization. ${ }^{32}$ In addition, such information fail to measure the impact on the overall organization. ${ }^{33}$ Furthermore, 
traditional performance measurement has been criticized for creating single focus and short-term orientation, lacking strategic focus, and discouraging continuous improvement ${ }^{24}$

Although traditional financial performance measures offer an easy way of measuring the quantitative part of the performance of hotels, they have a serious limitation that they cannot recognize intangible factors, such as customer/employee satisfaction, customer equity, and the brand image of the hotels. ${ }^{34}$ The non-financial indicators better reflect the investment and the performance of the more intangible aspects, which are so good at predicting the future financial performance. These intangibles can be a source of sustainable competitive advantage and are the resources that the organization owns. Also, they are not easily imitable ${ }^{22}$ The fundamental factor to the success of any organization relies on the increasing role of intangible assets in creating value. ${ }^{35}$

Furthermore, ${ }^{22}$ point out the mistakes that organizations make when trying to measure the non-financial performance include: (1) Lack of alignment between measurements with strategy : A key challenge is to determine which non-financial measures need to be implemented; (2) Validating the measurements: Do not validate the model, which leads to measure many things, and most of them are irrelevant; (3) Setting up the right goals and measures; and (4) Wrong measurements: Companies use metrics that have no statistical validity. According to ${ }^{23}$ most organizations use formal performance measurement systems that are extensions of their financial reports. The traditional financial accounting measures can give misleading signals for continuous improvement and innovation in organizations, and they are generally non-aligned with the capabilities and skills required for today's organizations in the preparation of their future. The measurement systems have been recognized as crucial elements to improving business performance and organizations.

The BSC suggests a combination of financial performance measures, with due attention to customer requirements, business processes and long-term sustainability. The BSC is reflected by the balance between the lagging indicators that represent the results of measurements, the past, and leading indicators representative of the future trends that will affect the results on the future. Moreover, the BSC does not only translate strategy into operational terms; it also aligns organizations with strategy, focusing business units and employees about their role in performing tasks. The BSC complements traditional financial performance measures with three additional perspectives, the customer, internal process, and learning and growth, as shown in Figure 1, allowing matching the accompanying financial measures for monitoring progress in building the capabilities and acquiring the intangible assets that are crucial for future growth. ${ }^{22}$

The BSC re-dimensioned the relative importance of the financial dimension within enterprise management. It merely postulates that other dimensions (the customer, learning and growth, and internal process) are equally important. Hence, the four dimensions are perfectly "balanced". ${ }^{18}{ }^{36}$ have proposed that continuous improvement in each of the non-financial perspectives would be monitored to assess whether it is translated ultimately into financial performance. If intangible investments did not result in improved financial performance, managers would need to redraw the strategy map. ${ }^{37}$

The first step in management processes creation for the implementation of the strategy involves the construction of a consistent and reliable framework that represents the network of relationships that lead to the achievement of objectives and the implementation of strategy. This framework is known as the "strategy map", ${ }^{22}$ which is a series of cause-and-effect linkages among objectives of the four Balanced Scorecard perspectives ${ }^{\mathbf{1 0 , 3 6 , 3 7}} \mathrm{A}$ strategy map for a BSC is a causal map depicting relations between various performance measures and corporate objectives. Causal maps express the judgment that certain events or actions will lead to particular outcomes. ${ }^{\mathbf{3 5 , 3 8 , 3}}$

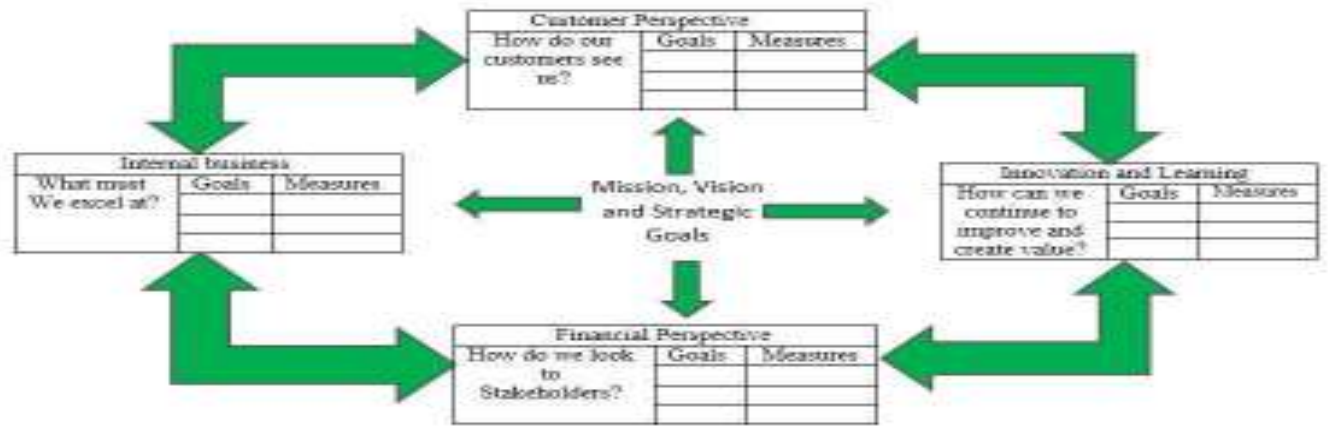


The main characteristic of The BSC is the presentation of a mixture of both financial and non-financial measures in order to establish a complete view regarding the organization's performance, ${ }^{32}$ as it mixes different measures: Financial and operational, and qualitative and quantitative. ${ }^{1}$ also links long-term strategic objectives with short-term actions. ${ }^{40}$ Moreover, ${ }^{9}$ points out that the BSC reflects the balance between short-term operational controls and long-term vision, strategy and objectives, lagging and leading indicators, and between external and internal performance perspectives.

Organizations should focus on the Key Performance Indicators (KPIs) of each of the four Balanced Scorecard perspectives for achieving the strategic plan. ${ }^{41} \mathrm{In}$ order to secure an easy review process of the property performance and enable managers to monitor their performance relative to goals, a selection of the most significant KPIs for each perspective is performed as follow ${ }^{25,29}$ :

1- Customer perspective (how an organization should appear to customers): It focuses on customer satisfaction, market share, new customer acquisition, customer retention, and customer profitability. Customer measures refer to the degree of meeting the customer's needs and include the price level, customers' rankings, matching of deliveries with customers' specification, promptness of service delivery, percentage of new customers, and percentage of customers kept. ${ }^{42}$

The customers usually have four main concerns regarding the product or service: Time, quality, performance and service, and cost. Therefore, the company has to align its targets according to these four elements, and subsequently transform these targets into specific measures..$^{\mathbf{1 0 , 3 2}}$

2- Internal business perspective (what business processes the organization should excel at): It inherently focuses on the design, delivery of the services, and the degree of excellence achieved. ${ }^{9}$ Furthermore, this perspective measures the internal business processes, core competencies, and technologies that would satisfy stakeholders and customers ${ }^{43}$ The internal measures for the Balanced Scorecard should aim at quality, employee skills and productivity. In addition, ${ }^{12}$ have mentioned that the indicators the manager can use to measure the internal performance of the business include: employee turnover, revenue by segment, complaint responses, etc. While ${ }^{10}$ have argued that an organization's ability to innovate, improve, and learn ties directly to its value. Therefore, only through the ability to launch new products, create more value for customers, and improve operating efficiencies continually can the organization penetrate new markets and increase revenues and margins - in short, grow, and thereby increase the shareholder value. ${ }^{44}$

3- Learning and growth perspective (innovation and learning) (how organization would sustain its ability to change and improve): It comes from three principle sources: people, systems, and organizational procedures. Learning and growth activities focus on translating strategies into action to enhance the ability of the organization, through its employees, to compete in the future and to achieve its current and long-term goals. ${ }^{45}$ Learning and growth measures focus on factors that facilitate continuous improvement in the organization such as employee satisfaction, employee suggestions, employee retention, employee productivity, computerization, and training and development sessions for employees. ${ }^{30}$ Finally, this perspective enables managers to build a complete strategy map by defining the employee capabilities and skills, technology, and corporate the climate needed to improve and support an effective strategy for the future. ${ }^{\mathbf{1 2}}$

4- Finally, the financial perspective (how the organization should appear to stakeholders): It is still the most commonly used measurement tool in performance measurement and management accounting. These measures focus on what has happened in the past and include mainly those measures dealing with organizational profitability, growth, and shareholder value. Moreover, key goals and measures here generally involve [gross and/or net] profitability, return on capital employed, economic value added, sales growth, market position and share, cash flow, etc. ${ }^{4}$ However, financial objectives reflect economic consequences of actions already taken in the other perspectives. ${ }^{43}$

Importantly, it should also be noted that a causal relationship is overtly recognized between the four perspectives, with the training programs provided for improving employees' skills and an investment in information technology (learning and growth perspective) leads to an improvement in delivering service (an 
internal process), which also leads to customer satisfaction and loyalty (customer perspective), and this, in turn, will increase revenue and profits (financial perspective). ${ }^{37,46,47}$ Table 1 lists examples of goals and measures that may appear in each of the four measurement perspectives.

Table (1): Examples of Quadrant BSC Goals and Measures

\begin{tabular}{|c|c|c|}
\hline & $\begin{array}{c}\text { Goals } \\
\text { (What do the organizations have to do?) }\end{array}$ & $\begin{array}{c}\text { Measures } \\
\text { (How do organizations know if they are achieving } \\
\text { their goals?) }\end{array}$ \\
\hline Financial & $\begin{array}{c}\text { - Achieve a higher return on investment } \\
\text { - Achieve significant revenue from new product } \\
\text { launch } \\
\text { - Maximize profitability } \\
\text { - Delight shareholders } \\
\text { - Achieve cost reduction }\end{array}$ & $\begin{array}{c}\text { - ROI, ROCE } \\
\text { - Revenue growth } \\
\text { - Unit costs } \\
\text { - Value added measures } \\
\text { - Cash flow }\end{array}$ \\
\hline Customer & $\begin{array}{l}\text { - Dominate major markets } \\
\text { - Delight targeted customers } \\
\text {-Increase revenue through repeat purchases } \\
\text {-Grow business in a selected target group } \\
\text { - Create responsive supply }\end{array}$ & $\begin{array}{c}\text { - Market share } \\
\text { - Customer satisfaction } \\
\text { - Survey results } \\
\text { - Customer retention over } \\
\text { time } \\
\text { - Customer acquisition from } \\
\text { target group } \\
\text { - On-time delivery }\end{array}$ \\
\hline $\begin{array}{l}\text { Internal } \\
\text { Business } \\
\text { Processes }\end{array}$ & $\begin{array}{l}\text { - Continually challenge competitor products in the } \\
\text { market place } \\
\text { - Compete on product reliability } \\
\text { - Design productivity } \\
\text { - Compete on product delivery channel mix }\end{array}$ & $\begin{array}{c}\text { - Time to market for next } \\
\text { generation of products } \\
\text { - Production defect rates } \\
\text { - Efficiency } \\
\text { - Volumes of transactions } \\
\text { conducted through each of delivery channels }\end{array}$ \\
\hline $\begin{array}{l}\text { Learning } \\
\qquad \& \\
\text { Growth }\end{array}$ & $\begin{array}{l}\text { - Develop a skilled workforce } \\
\text { - Value staff } \\
\text { - Create organizational alignment } \\
\text { - Provide internal information }\end{array}$ & $\begin{array}{c}\text { - Number of training hours completed per head } \\
\text { - Employee retention } \\
\text { - Peer evaluation measures } \\
\text { within/between teams } \\
\text { - Information availability } \\
\text { - Employee satisfaction } \\
\text { - Turnover rates }\end{array}$ \\
\hline
\end{tabular}

Source : ${ }^{40,48}$

In order to develop and implement the Balanced Scorecard, the organization would have to follow certain steps as mentioned by ${ }^{10,12,40,43}$.

- The first process: Clarify the vision: During this process managers develop a Balanced Scorecard that will state the general goals and measures to be accomplished, and translate the vision into strategy.

- The second process: Communicate and link strategic objectives and measures: Managers communicate their strategy up and down the organization and link it to departmental and individual objectives.

- The third process: Business Planning: This phase enables organizations to integrate their business and financial plans, set targets, and align strategic initiatives. 
-The fourth process: Feedback and learning: Existing feedback and review processes focus on whether the company, its departments, or its individual employees have met their budgeted financial goals.

The purpose of the BSC is to improve management effectiveness by having a shared and actionable view of the strategy. It also provides a generic framework to translate strategy into operational terms, a clear line of sight to the vision and strategy of the organization, and feedback and guidance. Also, it is a tool for communicating the strategy and the processes and systems required for strategy implementation. Furthermore, it creates a system approach or an integrated strategic management process, and draws a cause and effect roadmap to stakeholder value-shareholder, customer, and employee. Moreover, it provides a balance between current performance and long term competitive abilities financial and non-financial. ${ }^{33}$ Additionally, the initial objectives of the Balanced Scorecard are the value creation, considering the intangible and intellectual capital as opposed to the traditional systems of financial performance, ${ }^{22}$ and improving internal and external communications. ${ }^{49,50}$

\section{The importance of implementing the BSC}

Among the benefits of applying the Balanced Scorecard, these are the most significant: The Balanced Scorecard helps align the business actions and activities to vision and strategy; ${ }^{\mathbf{3 7 , 5 1 , 5 2}}$ the Balanced Scorecard provides management with a comprehensive picture of business operations; it facilitates communication and understanding of business goals and strategies at all levels of an organization; initiatives are continually measured and evaluated against industry standards $;{ }^{23}$ it also provides strategic feedback and learning; ${ }^{10}$ it achieves unique competitive advantage through reduced time-frames and improved processes; it improves decisions and better solutions; ${ }^{33}$ and it drives change and ${ }^{35}$ continuous improvement. ${ }^{53}$

\section{The Balanced Scorecard in the hospitality industry}

One framework that provides a consistent approach to successfully manage the business performance in the hospitality industry is the Balanced Scorecard. This can be proved by the successful documented experience with the Balanced Scorecard implementation and use by Hilton hotels and Marriott franchise, White Lodging Services, both worldwide recognized hotelier brands. ${ }^{3}$

\section{Examples of hospitality industry related BSC objectives: ${ }^{18,44}$}

a. The customer dimension: Increase in market share, increase in repeat business, increase in guest satisfaction, improve customer profitability, increase brand awareness, reduce customer complaints, and increase the number of new customers.

b. The learning and growth dimension: Adherence to recruitment procedures, training and development programs, performance appraisals completed, control of staff turnover, increase in knowledge, and control payroll as percentage of turnover.

c. The internal process dimension: Improve reservations efficiency, check-in and check-out efficiency, time and motion cleaning of rooms, food and beverage cost efficiency, and control property maintenance.

d. The financial dimension: Increase average room rate, increase revenue per available room, increase nonroom revenue, control variable cost, and reduce fixed cost.

\subsection{Criticism of the Balanced Scorecard}

Most of the criticisms of the Balanced Scorecard model can be summarized into the following:

Filtering: The most common criticism of the Balanced Scorecard is termed filtering or choosing specific measures to report. According to ${ }^{54}$, the idea of limiting the number of measures in a perspective reduces the value of lead indicators. ${ }^{46}$

Causality (cause-effect): Another criticism of the Balanced Scorecard surrounds the claim of causality among the perspectives, that the causality links among the four perspectives are ambiguous and weak at best. ${ }^{\mathbf{5 5}}$

Clustering: Another criticism of the Balanced Scorecard is clustering or grouping all measures into four perspectives. ${ }^{54}$ Although ${ }^{40}$ have addressed this issue by saying that some organizations may need more than four 
perspectives, or the perspective names may need to be modified to meet the needs of the organization or industry, this issue still arises.

General criticisms: Other criticisms include that the BSC does not incorporate environmental, community, or social aspects, which are a growing concern for stakeholders and can negatively impact an organization if not properly assessed. In addition, it does not incorporate competition or technological development, making it static in a global environment where competition and technology are continually changing. ${ }^{\mathbf{3 2 , 5 6}}$ Also, some argue that any type of planning is futile because organizations are too mechanical and resistant to change because organizational culture prohibits it, and there is a separation of planners and operators. ${ }^{57}$ As well, critics of the BSC hold that the system is not useful in large organizations as a corporate management system. ${ }^{46,58}$ Additionally, it is considered to be hard for an organization to implement performance measures for new actions. ${ }^{32}$ Furthermore, the BSC does not include some intangible factors, such as the company's image, competencies, culture, external stakeholders and employee morale. Moreover, it is hard to standardize performance scores of an organization. ${ }^{19,34}$

\section{Methodology}

The sample chosen in this study includes five stars hotels in Greater Cairo. These categories of hotels are chosen to be more knowledgeable and to have a basic understanding and acquaintance with the topic of research in order to obtain meaningful data. Furthermore, the target population of the study is composed of 125 hotels' managers (including: Regional Managers, Assistant General Managers and Department Managers); it has been randomly selected.

A total of 150 questionnaires have been distributed and 130 are collected (for a response rate of $86 \%$ ). Only 125 are valid after the elimination of the incomplete ones.

The questionnaire is composed of two sections: The first section is designed to elicit demographic data of the respondents. The second section of the questionnaire aims to investigate BSC awareness and use within hotels, clarify the KPI in hospitality industry, identify the attitude of hotels' managers toward the BSC, and rate the importance of each item of the four perspectives in the BSC when evaluating a hotel's performance.

The questionnaire has been structured that each BSC attribute is rated using a 5-point Likert scale, ranging from 1 (least important) to 5 (most important), in the attributes' part. A list of four perspectives has been generated from the review of literature. These factors are: Customer perspective, financial perspective, internal business perspective, and learning and growth perspective. Through the above process, $\mathbf{3 5}$ initial items have been generated in attempting to cover the BSC attributes and measure the four perspectives and their sub-dimension in the BSC model. This has included $\mathbf{9}$ items supporting financial perspective, $\mathbf{1 0}$ items for customer perspective, $\mathbf{8}$ items regarding internal business, and $\mathbf{8}$ items measuring learning and growth perspective; they have been chosen based on previous studies as well as interviews with hospitality industry professionals and experts. The items measured are listed as follows:

Financial Perspective: Return on investment (ROI), revenue per available room (Rev PAR), revenue per available guest (Rev PAG), return on sales (ROS), revenue growth rate, economic value added (EVA), return on capital employed ( ROCE), return on assets (ROA), and cost reduction.

Customer Perspective: Customer retention, customer satisfaction, customer complaints, customer profitability, market share, new customer acquisition, hotel image, market segmentation, customer value, and quick response to customer needs.

Internal Business: Occupancy rate, technology adaptation ratio, restaurant seat turnover, customer orientation, service failure rate, food and beverage sales per guest, check-in/out time, and inventory turnover.

Learning and Growth Perspective: Employee satisfaction, training levels and time, compensation, employee's job aptitude, employee retention, union relation, managerial leadership, and control of staff turnover. 


\section{Results}

The first section provides background information on the respondents of the questionnaire. Demographic profiles of respondents show that more than half of the respondents hold Assistant General Manager, Regional Manager and Department Manager positions. In terms of age, approximately $84 \%$ of the respondents are between 41 and 50 years old. A majority of respondents falls into the category of 11-20 years of hotel work experience.

Table (2): The importance of each type of the performance measures

\begin{tabular}{|c|c|c|c|c|c|c|c|c|}
\hline \multicolumn{2}{|c|}{ Performance measures } & $\begin{array}{c}\text { (5) Very } \\
\text { important }\end{array}$ & $\begin{array}{c}(4) \\
\text { Important }\end{array}$ & $\begin{array}{c}(3) \\
\text { Neutral }\end{array}$ & $\begin{array}{c}(2) \\
\text { Not very } \\
\text { important }\end{array}$ & $\begin{array}{c}(1) \\
\text { Unimportant }\end{array}$ & Mean & $\begin{array}{c}\text { Standard } \\
\text { deviation }\end{array}$ \\
\hline \multirow{2}{*}{$\begin{array}{c}\text { Financial } \\
\text { measures }\end{array}$} & Frequencies & 122 & 3 & 0 & 0 & 0 & 4.9760 & .15366 \\
\cline { 2 - 9 } & Percentage & $97.6 \%$ & $2.4 \%$ & 0 & 0 & 0 & \multirow{2}{*}{4.0800} & .57642 \\
\hline $\begin{array}{c}\text { Non- } \\
\text { financial } \\
\text { measures }\end{array}$ & Frequencies & 24 & 89 & 10 & 2 & 0 & \\
\cline { 2 - 9 } & Percentage & $19.2 \%$ & $71.2 \%$ & $8 \%$ & $1.6 \%$ & 0 & \\
\hline
\end{tabular}

The results in Table (2) indicate that despite the competitive environment of nowadays, hotels' managers still focus on traditional financial measures for measuring hotel performance with the mean of (4.9760) than the nonfinancial measures with the mean of (4.0800). However, it is worth mentioning that the traditional financial measures may be misleading and insufficient, especially in areas related to the development and innovation of the organization.

Table (3): Awareness of the term Balanced Scorecard

\begin{tabular}{|c|c|c|}
\hline & Frequencies & Percentage \\
\hline Yes & 125 & $100 \%$ \\
\hline No & 0 & $0 \%$ \\
\hline
\end{tabular}

Table (3) indicates that all respondents are familiar with the term Balanced Scorecard in the hospitality industry and aware of it.

Table (4): How the respondents learn about the Balanced Scorecard

\begin{tabular}{|l|c|c|}
\hline & Frequencies & Percentage \\
\hline From your experience at hotel management & 76 & $60.8 \%$ \\
\hline From other staff members with previous experience and knowledge about the BSC & 46 & $36.8 \%$ \\
\hline Through attending seminars and training sessions about BSC & 3 & $2.4 \%$ \\
\hline From professional journals & 0 & 0 \\
\hline From financial press & 0 & 0 \\
\hline
\end{tabular}




\begin{tabular}{|l|c|c|}
\hline From books & 0 & 0 \\
\hline From academic literature & 0 & 0 \\
\hline
\end{tabular}

Table (4) shows that $60.8 \%$ of the respondents assure learning about the Balanced Scorecard from their work experience at hotel management, while $36.8 \%$ has known about the BSC from other staff members and managers with previous experience and knowledge about it. On the other hand, only $2.4 \%$ has learnt about the Balanced Scorecard through attending seminars and training sessions about the BSC.

Table (5): Respondents use of the Balanced Scorecard

\begin{tabular}{|c|c|c|}
\hline & Frequencies & Percentage \\
\hline Yes & 125 & $100 \%$ \\
\hline No & 0 & $0 \%$ \\
\hline
\end{tabular}

As shown in Table (5), respondents have assured that they use the Balanced Scorecard to measure their hotels performance.

Table (6): How long has the hotel used the Balanced Scorecard

\begin{tabular}{|c|c|c|}
\hline & Frequencies & Percentage \\
\hline Less than 1 year & 74 & $59.2 \%$ \\
\hline $1-3$ years & 17 & $13.6 \%$ \\
\hline More than 3 years & 34 & $27.2 \%$ \\
\hline
\end{tabular}

As shown in Table (6), more than half of the respondents (59.2\%) have used the Balanced Scorecard for less than one year in their hotels, while the percentage of $(27.2 \%)$ of the respondents has clarified their use of the BSC for more than 3 years. In addition, the percentage of (13.6\%) has been using the BSC from 1 to 3 years. Therefore, this indicates that the BSC is a new approach that has been recently applied in hospitality management.

Table (7): The BSC perspective achieving the highest application in the hotels

\begin{tabular}{|c|c|c|c|}
\hline \multicolumn{2}{|c|}{ Business Areas } & Yes & No \\
\hline \multirow{2}{*}{ Customer } & Frequencies & 125 & 0 \\
\cline { 2 - 4 } & Percentage & $100 \%$ & 0 \\
\hline Internal business & Frequencies & 3 & 122 \\
\cline { 2 - 4 } & Percentage & $2.4 \%$ & $97.6 \%$ \\
\hline Learning and growth & Frequencies & 5 & 120 \\
\hline
\end{tabular}




\begin{tabular}{|c|c|c|c|}
\hline & Percentage & $4 \%$ & $96 \%$ \\
\hline \multirow{2}{*}{ Financial } & Frequencies & 125 & 0 \\
\cline { 2 - 4 } & Percentage & $100 \%$ & 0 \\
\hline
\end{tabular}

As displayed in Table (7), the respondents have mentioned that the dimensions used most for performance measurement in their hotels are customer and financial dimensions, while hotels managements still pay little attention to both internal business and learning and growth dimensions.

Table (8): The key performance indicators (KPIs) used in hotels to evaluate performance

\begin{tabular}{|c|c|c|c|c|c|c|c|}
\hline & & $\begin{array}{l}\text { (3) } \\
\text { Used } \\
\text { regularly }\end{array}$ & $\begin{array}{c}(2) \\
\text { Used } \\
\text { rarely }\end{array}$ & $\begin{array}{l}\text { (1) } \\
\text { Not } \\
\text { used }\end{array}$ & Mean & $\begin{array}{l}\text { Standard } \\
\text { Deviation }\end{array}$ & Rank \\
\hline \multirow{2}{*}{$\begin{array}{l}\text { 1- Measure of customers' } \\
\text { satisfaction through surveys and } \\
\text { number of complaints }\end{array}$} & Frequencies & 125 & 0 & 0 & \multirow{2}{*}{3.0000} & \multirow{2}{*}{.00000} & \multirow[t]{2}{*}{1} \\
\hline & Percentage & $100 \%$ & & & & & \\
\hline \multirow{2}{*}{$\begin{array}{l}\text { 2- Market share of a specific type } \\
\text { of customer or market }\end{array}$} & Frequencies & 125 & 0 & 0 & \multirow{2}{*}{3.0000} & \multirow{2}{*}{.00000} & \multirow[t]{2}{*}{2} \\
\hline & Percentage & $100 \%$ & & & & & \\
\hline \multirow[t]{2}{*}{ 3- Number of new products } & Frequencies & 1 & 119 & 5 & \multirow{2}{*}{1.9680} & \multirow{2}{*}{.21761} & \multirow[t]{2}{*}{5} \\
\hline & Percentage & $0.8 \%$ & $95.2 \%$ & $4 \%$ & & & \\
\hline \multirow[t]{2}{*}{ 4- On-time deliveries } & Frequencies & 125 & 0 & 0 & \multirow{2}{*}{3.0000} & \multirow{2}{*}{.00000} & \multirow[t]{2}{*}{3} \\
\hline & Percentage & $100 \%$ & & & & & \\
\hline \multirow[t]{2}{*}{ 5-Employees' satisfaction rates } & Frequencies & 2 & 64 & 59 & \multirow{2}{*}{1.5440} & \multirow{2}{*}{.53134} & \multirow[t]{2}{*}{7} \\
\hline & Percentage & $1.6 \%$ & $51.2 \%$ & $47.2 \%$ & & & \\
\hline \multirow{2}{*}{$\begin{array}{l}\text { 6- Employees' education and } \\
\text { skill levels }\end{array}$} & Frequencies & 2 & 5 & 118 & \multirow{2}{*}{1.0720} & \multirow{2}{*}{.31562} & \multirow[t]{2}{*}{8} \\
\hline & Percentage & $1.6 \%$ & $4 \%$ & $94.4 \%$ & & & \\
\hline \multirow[t]{2}{*}{ 7- Revenue growth } & Frequencies & 125 & 0 & 0 & \multirow{2}{*}{3.0000} & \multirow{2}{*}{.00000} & \multirow[t]{2}{*}{4} \\
\hline & Percentage & $100 \%$ & & & & & \\
\hline \multirow[t]{2}{*}{ 8- Revenue from new products } & Frequencies & 3 & 70 & 52 & \multirow{2}{*}{1.6080} & \multirow{2}{*}{.53726} & \multirow[t]{2}{*}{6} \\
\hline & Percentage & $2.4 \%$ & $56 \%$ & $41.6 \%$ & & & \\
\hline 9- Environmental and social & Frequencies & 1 & 1 & 123 & 1.0240 & .19935 & 9 \\
\hline
\end{tabular}




\begin{tabular}{|l|l|l|l|l|l|l|}
\hline responsibility & Percentage & $0.8 \%$ & $0.8 \%$ & $98.4 \%$ & & \\
\hline
\end{tabular}

Table 8 indicates that the key performance indicators (KPIs) hotels use to evaluate their performance are respectively customers' satisfaction, market share, on-time deliveries, revenue growth, number of new products offered, revenue from new products, employees' satisfaction rates, employees' education and skill levels, and finally environmental and social responsibility.

Table (9): The importance of the following objectives for hotels' managers

\begin{tabular}{|c|c|c|c|c|c|c|c|c|c|}
\hline & & $\begin{array}{l}(5) \\
\text { Very } \\
\text { import } \\
\text { ant }\end{array}$ & $\begin{array}{c}(4) \\
\text { Impor } \\
\text { tant }\end{array}$ & $\begin{array}{c}(3) \\
\text { Neutr } \\
\text { al }\end{array}$ & $\begin{array}{c}(2) \\
\text { Not } \\
\text { very } \\
\text { import } \\
\text { ant }\end{array}$ & $\begin{array}{c}\text { (1) } \\
\text { Unimp } \\
\text { ortant }\end{array}$ & Mean & $\begin{array}{c}\text { Stand } \\
\text { ard } \\
\text { Deviat } \\
\text { ion }\end{array}$ & $\begin{array}{c}\operatorname{Ran} \\
\mathrm{k}\end{array}$ \\
\hline \multirow{2}{*}{$\begin{array}{l}1- \\
\text { Increase } \\
\text { sales }\end{array}$} & $\begin{array}{l}\text { Frequenci } \\
\text { es }\end{array}$ & 115 & 10 & 0 & 0 & 0 & \multirow{2}{*}{$\begin{array}{c}4.920 \\
0\end{array}$} & \multirow{2}{*}{$\begin{array}{c}.2723 \\
8\end{array}$} & \multirow[t]{2}{*}{1} \\
\hline & Percentage & $92 \%$ & $8 \%$ & & & & & & \\
\hline \multirow{2}{*}{$\begin{array}{l}2- \\
\text { Increase } \\
\text { profits }\end{array}$} & $\begin{array}{l}\text { Frequenci } \\
\text { es }\end{array}$ & 107 & 18 & 0 & 0 & 0 & \multirow{2}{*}{$\begin{array}{c}4.856 \\
0\end{array}$} & \multirow{2}{*}{$\begin{array}{c}.3525 \\
0\end{array}$} & \multirow[t]{2}{*}{5} \\
\hline & Percentage & $\begin{array}{c}85.6 \\
\%\end{array}$ & $\begin{array}{c}14.4 \\
\%\end{array}$ & & & & & & \\
\hline \multirow{2}{*}{$\begin{array}{l}3 \text { - } \\
\text { Increase } \\
\text { revenue }\end{array}$} & $\begin{array}{l}\text { Frequenci } \\
\text { es }\end{array}$ & 111 & 14 & 0 & 0 & 0 & \multirow{2}{*}{$\begin{array}{c}4.888 \\
0\end{array}$} & \multirow{2}{*}{$\begin{array}{c}.3166 \\
4\end{array}$} & \multirow[t]{2}{*}{3} \\
\hline & Percentage & $\begin{array}{c}88.8 \\
\%\end{array}$ & $\begin{array}{c}11.2 \\
\%\end{array}$ & & & & & & \\
\hline \multirow{2}{*}{$\begin{array}{l}\text { 4- } \\
\text { Customer } \\
\text { satisfactio } \\
\text { n }\end{array}$} & $\begin{array}{l}\text { Frequenci } \\
\text { es }\end{array}$ & 72 & 53 & 0 & 0 & 0 & \multirow{2}{*}{$\begin{array}{c}4.576 \\
0\end{array}$} & \multirow{2}{*}{$\begin{array}{c}.4961 \\
8\end{array}$} & \multirow[t]{2}{*}{8} \\
\hline & Percentage & $\begin{array}{c}57.6 \\
\%\end{array}$ & $\begin{array}{c}42.4 \\
\%\end{array}$ & & & & & & \\
\hline \multirow{2}{*}{$\begin{array}{l}5- \\
\text { Increase } \\
\text { the } \\
\text { number of } \\
\text { customers }\end{array}$} & $\begin{array}{l}\text { Frequenci } \\
\text { es }\end{array}$ & 106 & 19 & 0 & 0 & 0 & \multirow{2}{*}{$\begin{array}{c}4.848 \\
0\end{array}$} & \multirow{2}{*}{$\begin{array}{c}.3604 \\
7\end{array}$} & \multirow[t]{2}{*}{6} \\
\hline & Percentage & $\begin{array}{c}84.8 \\
\%\end{array}$ & $\begin{array}{c}15.2 \\
\%\end{array}$ & & & & & & \\
\hline \multirow{2}{*}{$\begin{array}{l}6- \\
\text { Increase } \\
\text { market } \\
\text { share }\end{array}$} & $\begin{array}{l}\text { Frequenci } \\
\text { es }\end{array}$ & 110 & 15 & 0 & 0 & 0 & \multirow{2}{*}{$\begin{array}{c}4.880 \\
0\end{array}$} & \multirow{2}{*}{$\begin{array}{c}.3262 \\
7\end{array}$} & \multirow[t]{2}{*}{4} \\
\hline & Percentage & $88 \%$ & $12 \%$ & & & & & & \\
\hline
\end{tabular}




\begin{tabular}{|c|c|c|c|c|c|c|c|c|c|}
\hline \multirow{2}{*}{$\begin{array}{l}\text { 7- } \\
\text { Increase } \\
\text { productivi } \\
\text { ty }\end{array}$} & $\begin{array}{l}\text { Frequenci } \\
\text { es }\end{array}$ & 102 & 23 & 0 & 0 & 0 & \multirow{2}{*}{$\begin{array}{c}4.816 \\
0\end{array}$} & \multirow{2}{*}{$\begin{array}{c}.3890 \\
4\end{array}$} & \multirow[t]{2}{*}{7} \\
\hline & Percentage & $\begin{array}{c}81.6 \\
\%\end{array}$ & $\begin{array}{c}18.4 \\
\%\end{array}$ & & & & & & \\
\hline \multirow{2}{*}{$\begin{array}{l}8 \text { - } \\
\text { Improve } \\
\text { the } \\
\text { employees } \\
\text { ' skills }\end{array}$} & $\begin{array}{l}\text { Frequenci } \\
\text { es }\end{array}$ & 4 & 63 & 5 & 38 & 15 & \multirow{2}{*}{$\begin{array}{c}3.024 \\
0\end{array}$} & \multirow{2}{*}{$\begin{array}{c}1.194 \\
50\end{array}$} & \multirow[t]{2}{*}{9} \\
\hline & Percentage & $3.2 \%$ & $\begin{array}{c}50.4 \\
\%\end{array}$ & $4 \%$ & $\begin{array}{c}30.4 \\
\%\end{array}$ & $12 \%$ & & & \\
\hline \multirow{2}{*}{$\begin{array}{l}\text { 9- } \\
\text { Increase } \\
\text { employees } \\
\text { satisfactio } \\
\text { n. }\end{array}$} & $\begin{array}{l}\text { Frequenci } \\
\text { es }\end{array}$ & 9 & 51 & 2 & 23 & 40 & \multirow{2}{*}{$\begin{array}{c}2.728 \\
0\end{array}$} & \multirow{2}{*}{$\begin{array}{c}1.450 \\
12\end{array}$} & \multirow[t]{2}{*}{10} \\
\hline & Percentage & $7.2 \%$ & $\begin{array}{c}40.8 \\
\%\end{array}$ & $\begin{array}{c}1.6 \\
\%\end{array}$ & $\begin{array}{c}18.4 \\
\%\end{array}$ & $32 \%$ & & & \\
\hline \multirow{2}{*}{$\begin{array}{l}10- \\
\text { Improve } \\
\text { the quality } \\
\text { of } \\
\text { products/s } \\
\text { ervices }\end{array}$} & $\begin{array}{l}\text { Frequenci } \\
\text { es }\end{array}$ & 113 & 12 & 0 & 0 & 0 & \multirow{2}{*}{$\begin{array}{c}4.904 \\
0\end{array}$} & \multirow{2}{*}{$\begin{array}{c}.2957 \\
8\end{array}$} & \multirow[t]{2}{*}{2} \\
\hline & Percentage & $\begin{array}{c}90.4 \\
\%\end{array}$ & $9.6 \%$ & & & & & & \\
\hline
\end{tabular}

The respondents have been asked to rate the importance of the objectives for their hotels. It is noticeable that the financial areas are considered the most important objectives for hotels managements; it got higher rates represented in increasing sales, improving the quality of products/services, increasing revenue, increasing market share, increasing profits, increasing the number of customers, and increasing productivity. These results confirm the study of Kim and Lee. ${ }^{34}$ Also, the customer perspective is considered the second objective represented in customer satisfaction; and finally the interest of employees is at the last stage represented in improving the employees' skills and increasing employees' satisfaction.

Table (10): Attitude of hotels' managers toward the BSC

\begin{tabular}{|c|c|c|c|c|c|c|c|c|}
\hline & & $\begin{array}{l}\text { (5) } \\
\text { Strongly } \\
\text { agree }\end{array}$ & $\begin{array}{c}(4) \\
\text { Agree }\end{array}$ & $\begin{array}{c}(3) \\
\text { Neutral }\end{array}$ & $\begin{array}{c}(2) \\
\text { Disagree }\end{array}$ & $\begin{array}{c}\text { (1) } \\
\text { Strongly } \\
\text { Disagree }\end{array}$ & Mean & $\begin{array}{l}\text { Standard } \\
\text { Deviation }\end{array}$ \\
\hline \multirow{2}{*}{$\begin{array}{l}1-\mathrm{BSC} \text { is an effective } \\
\text { performance } \\
\text { measurement system }\end{array}$} & Frequencies & 41 & 70 & 14 & 0 & 0 & \multirow{2}{*}{4.2160} & \multirow{2}{*}{.62970} \\
\hline & Percentage & $32.8 \%$ & $56 \%$ & $11.2 \%$ & & & & \\
\hline \multirow{2}{*}{$\begin{array}{l}\text { 2- My hotel is } \\
\text { satisfied with the use } \\
\text { of the BSC }\end{array}$} & Frequencies & 53 & 69 & 3 & 0 & 0 & \multirow[b]{2}{*}{4.4000} & \multirow[b]{2}{*}{.53882} \\
\hline & Percentage & $42.4 \%$ & $\begin{array}{c}55.2 \\
\%\end{array}$ & $2.4 \%$ & & & & \\
\hline 3- It is a performance & Frequencies & 91 & 33 & 1 & 0 & 0 & 4.7200 & .46835 \\
\hline
\end{tabular}




\begin{tabular}{|c|c|c|c|c|c|c|c|c|}
\hline $\begin{array}{l}\text { measurement tool } \\
\text { relevant for hotels }\end{array}$ & Percentage & $72.8 \%$ & $\begin{array}{c}26.4 \\
\%\end{array}$ & $0.8 \%$ & & & & \\
\hline \multirow{2}{*}{$\begin{array}{l}\text { 4- It is easy to apply } \\
\text { the BSC in hotels }\end{array}$} & Frequencies & 89 & 35 & 1 & 0 & 0 & \multirow{2}{*}{4.7040} & \multirow{2}{*}{.47560} \\
\hline & Percentage & $71.2 \%$ & $28 \%$ & $0.8 \%$ & & & & \\
\hline \multirow{2}{*}{$\begin{array}{l}\text { 5- It is easier to } \\
\text { achieve the goals of } \\
\text { the hotel when } \\
\text { applying the BSC }\end{array}$} & Frequencies & 60 & 59 & 4 & 2 & 0 & \multirow[b]{2}{*}{4.4160} & \multirow[b]{2}{*}{63733} \\
\hline & Percentage & $48 \%$ & $\begin{array}{c}47.2 \\
\%\end{array}$ & $3.2 \%$ & $1.6 \%$ & & & \\
\hline \multirow{2}{*}{$\begin{array}{l}\text { 6- It evaluates better } \\
\text { the strategy of the } \\
\text { hotel }\end{array}$} & Frequencies & 49 & 73 & 3 & 0 & 0 & \multirow[b]{2}{*}{4.3680} & \multirow[b]{2}{*}{.53183} \\
\hline & Percentage & $39.2 \%$ & $\begin{array}{c}58.4 \\
\%\end{array}$ & $2.4 \%$ & & & & \\
\hline \multirow{2}{*}{$\begin{array}{l}\text { 7- It balances the long- } \\
\text { term goals and short- } \\
\text { term goals of the } \\
\text { business }\end{array}$} & Frequencies & 55 & 68 & 2 & 0 & 0 & \multirow[b]{2}{*}{4.4240} & \multirow[b]{2}{*}{.52769} \\
\hline & Percentage & $44 \%$ & $\begin{array}{c}54.4 \\
\%\end{array}$ & $1.6 \%$ & & & & \\
\hline \multirow{2}{*}{$\begin{array}{l}\text { 8- With the BSC the } \\
\text { employees understand } \\
\text { better the strategy and } \\
\text { the vision of the } \\
\text { business }\end{array}$} & Frequencies & 30 & 95 & 0 & 0 & 0 & \multirow[b]{2}{*}{4.2400} & \multirow[b]{2}{*}{.42880} \\
\hline & Percentage & $24 \%$ & $76 \%$ & & & & & \\
\hline \multirow{2}{*}{$\begin{array}{l}\text { 9-Information from the } \\
\text { BSC can help } \\
\text { managers to improve } \\
\text { the customer } \\
\text { satisfaction }\end{array}$} & Frequencies & 77 & 48 & 0 & 0 & 0 & \multirow[b]{2}{*}{4.6160} & \multirow[b]{2}{*}{.48832} \\
\hline & Percentage & $61.6 \%$ & $\begin{array}{c}38.4 \\
\%\end{array}$ & & & & & \\
\hline \multirow{2}{*}{$\begin{array}{l}\text { 10- Information from } \\
\text { the BSC can help } \\
\text { managers to improve } \\
\text { the efficiency in } \\
\text { operation }\end{array}$} & Frequencies & 68 & 57 & 0 & 0 & 0 & \multirow[b]{2}{*}{4.5440} & \multirow[b]{2}{*}{.50006} \\
\hline & Percentage & $54.4 \%$ & $\begin{array}{c}45.6 \\
\%\end{array}$ & & & & & \\
\hline \multirow{2}{*}{$\begin{array}{l}\text { 11- Information from } \\
\text { the BSC can help } \\
\text { managers to improve } \\
\text { the employees' skills }\end{array}$} & Frequencies & 59 & 66 & 0 & 0 & 0 & \multirow[b]{2}{*}{4.4720} & \multirow[b]{2}{*}{.50122} \\
\hline & Percentage & $47.2 \%$ & $\begin{array}{c}52.8 \\
\%\end{array}$ & & & & & \\
\hline \multirow{2}{*}{$\begin{array}{l}\text { 12- Information from } \\
\text { the BSC can help } \\
\text { managers to increase } \\
\text { the employees' } \\
\text { satisfaction levels }\end{array}$} & Frequencies & 51 & 74 & 0 & 0 & 0 & \multirow[b]{2}{*}{4.4080} & \multirow[b]{2}{*}{.49344} \\
\hline & Percentage & $40.8 \%$ & $\begin{array}{c}59.2 \\
\%\end{array}$ & & & & & \\
\hline
\end{tabular}




\begin{tabular}{|c|c|c|c|c|c|c|c|c|}
\hline \multirow{2}{*}{$\begin{array}{l}\text { 13- Information from } \\
\text { the BSC can help } \\
\text { managers to increase } \\
\text { market share }\end{array}$} & Frequencies & 83 & 42 & 0 & 0 & 0 & \multirow[b]{2}{*}{4.6640} & \multirow[b]{2}{*}{.47424} \\
\hline & Percentage & $66.4 \%$ & $\begin{array}{c}33.6 \\
\%\end{array}$ & & & & & \\
\hline \multirow{2}{*}{$\begin{array}{l}14 \text { - Information from } \\
\text { the BSC can help } \\
\text { managers to improve } \\
\text { the products/services } \\
\text { delivery time to } \\
\text { customers }\end{array}$} & Frequencies & 76 & 49 & 0 & 0 & 0 & \multirow[b]{2}{*}{4.6080} & \multirow[b]{2}{*}{.49016} \\
\hline & Percentage & $60.8 \%$ & $\begin{array}{c}39.2 \\
5\end{array}$ & & & & & \\
\hline \multirow{2}{*}{$\begin{array}{l}15 \text { - Information from } \\
\text { the BSC can help } \\
\text { managers to increase } \\
\text { profits }\end{array}$} & Frequencies & 88 & 37 & 0 & 0 & 0 & \multirow[b]{2}{*}{4.7040} & \multirow[b]{2}{*}{.45833} \\
\hline & Percentage & $70.4 \%$ & $\begin{array}{c}29.6 \\
\%\end{array}$ & & & & & \\
\hline \multirow{2}{*}{$\begin{array}{l}16 \text { - Information from } \\
\text { the BSC can help } \\
\text { managers to reduce } \\
\text { costs }\end{array}$} & Frequencies & 80 & 45 & 0 & 0 & 0 & \multirow[b]{2}{*}{4.6400} & \multirow[b]{2}{*}{.48193} \\
\hline & Percentage & $64 \%$ & $36 \%$ & & & & & \\
\hline Total attitude & & & & & & & 4.5090 & .4359 \\
\hline
\end{tabular}

To understand the managers attitude toward implementing the Balanced Scorecard (BSC), the respondents have been asked to rate their level of agreement with a number of BSC attributes' statements listed above (in Table 10). The respondents have answered on a scale of one to five where one means 'Strongly Disagree' and five means 'Strongly agree'.

As shown above, the agreement level of respondents with all statements is positive with mean (4.5090) and standard deviation (.4359), which means that most managers' attitude is toward the scale of agree and strongly agree. This, in turn, leads to that managers have a positive attitude toward BSC.

Table (11): The importance of each attribute when evaluating hotels' performance

\begin{tabular}{|c|c|c|c|c|c|c|c|c|c|}
\hline & & $\begin{array}{c}(5) \\
\text { Very } \\
\text { import } \\
\text { ant }\end{array}$ & $\begin{array}{c}(4) \\
\text { Import } \\
\text { ant }\end{array}$ & $\begin{array}{c}(3) \\
\text { Neut } \\
\text { ral }\end{array}$ & $\begin{array}{c}(2) \\
\text { Not } \\
\text { very } \\
\text { import } \\
\text { ant }\end{array}$ & $\begin{array}{c}\text { (1) } \\
\text { Unimp } \\
\text { ortant }\end{array}$ & Mean & $\begin{array}{c}\text { Standa } \\
\text { rd } \\
\text { Deviat } \\
\text { ion }\end{array}$ & $\begin{array}{l}\mathrm{Ra} \\
\mathrm{nk}\end{array}$ \\
\hline \multicolumn{7}{|c|}{ 1- Financial Perspective: } & $\begin{array}{c}4.596 \\
4\end{array}$ & & \\
\hline \multirow{2}{*}{$\begin{array}{l}\text { - ROI } \\
\text { (Return } \\
\text { on } \\
\text { Investmen } \\
\text { t) }\end{array}$} & $\begin{array}{c}\text { Frequenc } \\
\text { ies }\end{array}$ & 92 & 32 & 1 & 0 & 0 & \multirow{2}{*}{$\begin{array}{c}4.728 \\
0\end{array}$} & \multirow{2}{*}{.46448} & \\
\hline & $\begin{array}{c}\text { Percentag } \\
\mathrm{e}\end{array}$ & $\begin{array}{c}73.6 \\
\%\end{array}$ & $25.6 \%$ & $\begin{array}{c}0.8 \\
\%\end{array}$ & 0 & 0 & & & \\
\hline
\end{tabular}




\begin{tabular}{|c|c|c|c|c|c|c|c|c|}
\hline \multirow{2}{*}{$\begin{array}{l}\text { - ROS } \\
\text { (Return } \\
\text { on Sales) }\end{array}$} & $\begin{array}{c}\text { Frequenc } \\
\text { ies }\end{array}$ & 90 & 35 & 0 & 0 & 0 & \multirow{2}{*}{$\begin{array}{c}4.720 \\
0\end{array}$} & \multirow{2}{*}{.45081} \\
\hline & $\begin{array}{c}\text { Percentag } \\
\mathrm{e}\end{array}$ & $72 \%$ & $28 \%$ & 0 & 0 & 0 & & \\
\hline \multirow{2}{*}{$\begin{array}{l}\text { - Revenue } \\
\text { Growth } \\
\text { Rate }\end{array}$} & $\begin{array}{c}\text { Frequenc } \\
\text { ies }\end{array}$ & 91 & 33 & 1 & 0 & 0 & \multirow{2}{*}{$\begin{array}{c}4.720 \\
0\end{array}$} & \multirow{2}{*}{.46835} \\
\hline & $\begin{array}{c}\text { Percentag } \\
\text { e }\end{array}$ & $\begin{array}{c}72.8 \\
\%\end{array}$ & $26.4 \%$ & $\begin{array}{c}0.8 \\
\%\end{array}$ & 0 & 0 & & \\
\hline \multirow{2}{*}{$\begin{array}{l}\text { - EVA } \\
\text { (Economi } \\
\text { c Value } \\
\text { Added) }\end{array}$} & $\begin{array}{c}\text { Frequenc } \\
\text { ies }\end{array}$ & 59 & 66 & 0 & 0 & 0 & \multirow{2}{*}{$\begin{array}{c}4.472 \\
0\end{array}$} & \multirow{2}{*}{.50122} \\
\hline & $\begin{array}{l}\text { Percentag } \\
\mathrm{e}\end{array}$ & $\begin{array}{c}47.2 \\
\%\end{array}$ & $52.8 \%$ & 0 & 0 & 0 & & \\
\hline \multirow{2}{*}{$\begin{array}{l}\text { - ROCE } \\
\text { (Return } \\
\text { On } \\
\text { Capital } \\
\text { Employed } \\
\text { ) }\end{array}$} & $\begin{array}{c}\text { Frequenc } \\
\text { ies }\end{array}$ & 61 & 64 & 0 & 0 & 0 & \multirow{2}{*}{$\begin{array}{c}4.488 \\
0\end{array}$} & \multirow[b]{2}{*}{.50187} \\
\hline & $\begin{array}{c}\text { Percentag } \\
\text { e }\end{array}$ & $\begin{array}{c}48.8 \\
\%\end{array}$ & $51.2 \%$ & 0 & 0 & 0 & & \\
\hline \multirow{2}{*}{$\begin{array}{l}\text {-ROA } \\
\text { (Return } \\
\text { On } \\
\text { Assets) }\end{array}$} & $\begin{array}{c}\text { Frequenc } \\
\text { ies }\end{array}$ & 57 & 68 & 0 & 0 & 0 & \multirow{2}{*}{$\begin{array}{c}4.456 \\
0\end{array}$} & \multirow{2}{*}{.50006} \\
\hline & $\begin{array}{c}\text { Percentag } \\
\text { e }\end{array}$ & $\begin{array}{c}45.6 \\
\%\end{array}$ & $54.4 \%$ & 0 & 0 & 0 & & \\
\hline \multirow[t]{2}{*}{$\begin{array}{l}\text { - Cost } \\
\text { reduction }\end{array}$} & $\begin{array}{c}\text { Frequenc } \\
\text { ies }\end{array}$ & 81 & 44 & 0 & 0 & 0 & \multirow{2}{*}{$\begin{array}{c}4.648 \\
0\end{array}$} & \multirow{2}{*}{.47952} \\
\hline & $\begin{array}{c}\text { Percentag } \\
\mathrm{e}\end{array}$ & $\begin{array}{c}64.8 \\
\%\end{array}$ & $35.2 \%$ & 0 & 0 & 0 & & \\
\hline \multirow{2}{*}{$\begin{array}{l}\text { - REV } \\
\text { PAR } \\
\text { Revenue } \\
\text { Per } \\
\text { Available } \\
\text { Room }\end{array}$} & $\begin{array}{c}\text { Frequenc } \\
\text { ies }\end{array}$ & 69 & 56 & 0 & 0 & 0 & \multirow[b]{2}{*}{$\begin{array}{c}4.552 \\
0\end{array}$} & \multirow[b]{2}{*}{.49929} \\
\hline & $\begin{array}{c}\text { Percentag } \\
\text { e }\end{array}$ & $\begin{array}{c}55.2 \\
\%\end{array}$ & $44.8 \%$ & 0 & 0 & 0 & & \\
\hline \multirow{2}{*}{$\begin{array}{l}\text { - REV } \\
\text { PAG }\end{array}$} & $\begin{array}{c}\text { Frequenc } \\
\text { ies }\end{array}$ & 73 & 52 & 0 & 0 & 0 & \multirow{2}{*}{$\begin{array}{c}4.584 \\
0\end{array}$} & \multirow{2}{*}{.49488} \\
\hline & $\begin{array}{c}\text { Percentag } \\
\mathrm{e}\end{array}$ & $\begin{array}{c}58.4 \\
\%\end{array}$ & $41.6 \%$ & 0 & 0 & 0 & & \\
\hline
\end{tabular}




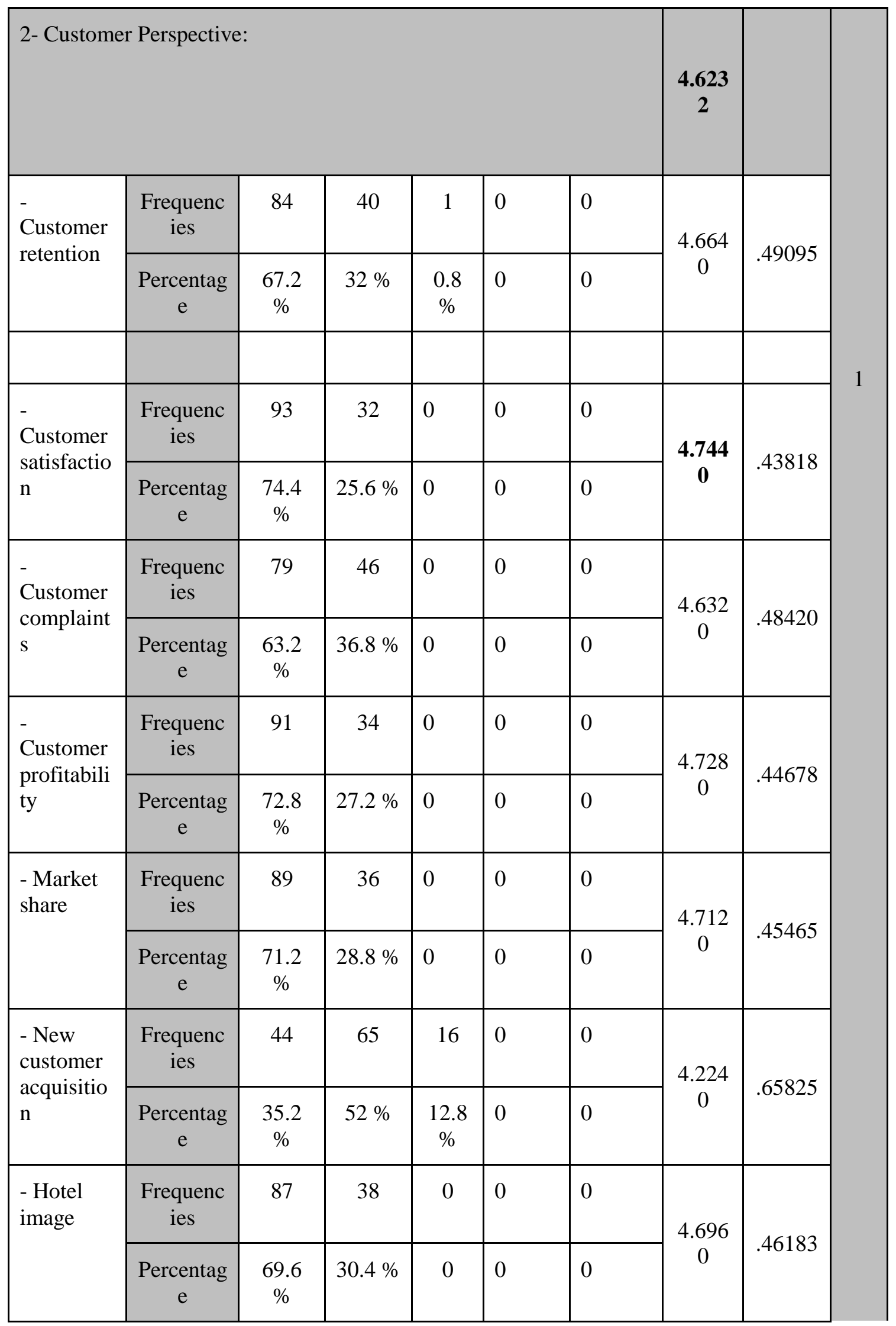




\begin{tabular}{|c|c|c|c|c|c|c|c|c|c|}
\hline \multirow{2}{*}{$\begin{array}{l}\text { - Market } \\
\text { segmentat } \\
\text { ion }\end{array}$} & $\begin{array}{c}\text { Frequenc } \\
\text { ies }\end{array}$ & 75 & 45 & 5 & 0 & 0 & \multirow{2}{*}{$\begin{array}{c}4.560 \\
0\end{array}$} & \multirow{2}{*}{.57361} & \\
\hline & $\begin{array}{c}\text { Percentag } \\
\mathrm{e}\end{array}$ & $60 \%$ & $36 \%$ & $4 \%$ & 0 & 0 & & & \\
\hline \multirow{2}{*}{$\begin{array}{l}\text { - } \\
\text { Customer } \\
\text { value }\end{array}$} & $\begin{array}{c}\text { Frequenc } \\
\text { ies }\end{array}$ & 69 & 56 & 0 & 0 & 0 & \multirow{2}{*}{$\begin{array}{c}4.552 \\
0\end{array}$} & \multirow{2}{*}{.49929} & \\
\hline & $\begin{array}{c}\text { Percentag } \\
\mathrm{e}\end{array}$ & $\begin{array}{c}55.2 \\
\%\end{array}$ & $44.8 \%$ & 0 & 0 & 0 & & & \\
\hline \multirow{2}{*}{$\begin{array}{l}\text { - Quick } \\
\text { response } \\
\text { to } \\
\text { customer } \\
\text { needs }\end{array}$} & $\begin{array}{c}\text { Frequenc } \\
\text { ies }\end{array}$ & 90 & 35 & 0 & 0 & 0 & \multirow{2}{*}{$\begin{array}{c}4.720 \\
0\end{array}$} & \multirow{2}{*}{.45081} & \\
\hline & $\begin{array}{c}\text { Percentag } \\
\mathrm{e}\end{array}$ & $72 \%$ & $28 \%$ & 0 & 0 & 0 & & & \\
\hline \multicolumn{7}{|c|}{3 - Internal Business: } & $\begin{array}{c}1.540 \\
0\end{array}$ & & \\
\hline \multirow{2}{*}{$\begin{array}{l}- \\
\text { Occupanc } \\
\text { y rate }\end{array}$} & $\begin{array}{c}\text { Frequenc } \\
\text { ies }\end{array}$ & 1 & 0 & 14 & 59 & 51 & \multirow[b]{2}{*}{$\begin{array}{c}1.728 \\
0\end{array}$} & \multirow[b]{2}{*}{.72263} & \\
\hline & $\begin{array}{c}\text { Percentag } \\
\mathrm{e}\end{array}$ & $0.8 \%$ & 0 & $\begin{array}{c}11.2 \\
\%\end{array}$ & $\begin{array}{c}47.2 \\
\%\end{array}$ & $40.8 \%$ & & & 3 \\
\hline \multirow{2}{*}{$\begin{array}{l}- \\
\text { Technolo } \\
\text { gy } \\
\text { adaptation } \\
\text { ratio }\end{array}$} & $\begin{array}{c}\text { Frequenc } \\
\text { ies }\end{array}$ & 0 & 0 & 7 & 63 & 55 & \multirow{2}{*}{$\begin{array}{c}1.616 \\
0\end{array}$} & \multirow{2}{*}{.59275} & \\
\hline & $\begin{array}{c}\text { Percentag } \\
\mathrm{e}\end{array}$ & 0 & 0 & $\begin{array}{l}5.6 \\
\%\end{array}$ & $\begin{array}{c}50.4 \\
\%\end{array}$ & $44 \%$ & & & \\
\hline \multirow{2}{*}{$\begin{array}{l}- \\
\text { Restauran } \\
\text { t seat } \\
\text { turnover }\end{array}$} & $\begin{array}{c}\text { Frequenc } \\
\text { ies }\end{array}$ & 0 & 1 & 0 & 84 & 40 & \multirow{2}{*}{$\begin{array}{c}1.696 \\
0\end{array}$} & \multirow{2}{*}{.51154} & \\
\hline & $\begin{array}{c}\text { Percentag } \\
\mathrm{e}\end{array}$ & 0 & $0.8 \%$ & & $\begin{array}{c}67.2 \\
\%\end{array}$ & $32 \%$ & & & \\
\hline \multirow{2}{*}{$\begin{array}{l}- \\
\text { Customer } \\
\text { orientatio } \\
n\end{array}$} & $\begin{array}{c}\text { Frequenc } \\
\text { ies }\end{array}$ & 0 & 0 & 2 & 39 & 84 & \multirow{2}{*}{$\begin{array}{c}1.344 \\
0\end{array}$} & \multirow{2}{*}{.50965} & \\
\hline & $\begin{array}{c}\text { Percentag } \\
\mathrm{e}\end{array}$ & 0 & 0 & $\begin{array}{l}1.6 \\
\%\end{array}$ & $\begin{array}{c}31.2 \\
\%\end{array}$ & $67.2 \%$ & & & \\
\hline $\begin{array}{l}\text { - Service } \\
\text { failure }\end{array}$ & $\begin{array}{c}\text { Frequenc } \\
\text { ies }\end{array}$ & 0 & 0 & 0 & 51 & 74 & $\begin{array}{c}1.408 \\
0\end{array}$ & .49344 & \\
\hline
\end{tabular}




\begin{tabular}{|c|c|c|c|c|c|c|c|c|c|}
\hline rate & $\begin{array}{c}\text { Percentag } \\
\text { e }\end{array}$ & 0 & 0 & 0 & $\begin{array}{c}40.8 \\
\%\end{array}$ & $59.2 \%$ & & & \\
\hline \multirow{2}{*}{$\begin{array}{l}\text { - Food } \\
\text { and } \\
\text { beverage } \\
\text { sales per } \\
\text { guest }\end{array}$} & $\begin{array}{l}\text { Frequenc } \\
\text { ies }\end{array}$ & 0 & 0 & 0 & 57 & 68 & \multirow{2}{*}{$\begin{array}{c}1.456 \\
0\end{array}$} & \multirow{2}{*}{.50006} & \\
\hline & $\begin{array}{c}\text { Percentag } \\
\text { e }\end{array}$ & 0 & 0 & 0 & $\begin{array}{c}45.6 \\
\%\end{array}$ & $54.4 \%$ & & & \\
\hline \multirow{2}{*}{$\begin{array}{l}\text { - Check- } \\
\text { in/out } \\
\text { time }\end{array}$} & $\begin{array}{c}\text { Frequenc } \\
\text { ies }\end{array}$ & 0 & 0 & 11 & 44 & 70 & \multirow{2}{*}{$\begin{array}{c}1.528 \\
0\end{array}$} & \multirow{2}{*}{.65471} & \\
\hline & $\begin{array}{c}\text { Percentag } \\
\text { e }\end{array}$ & 0 & 0 & $\begin{array}{c}8.8 \\
\%\end{array}$ & $\begin{array}{c}35.2 \\
\%\end{array}$ & $56 \%$ & & & \\
\hline \multirow{2}{*}{$\begin{array}{l}\text { - } \\
\text { Inventory } \\
\text { turnover }\end{array}$} & $\begin{array}{l}\text { Frequenc } \\
\text { ies }\end{array}$ & 0 & 0 & 9 & 50 & 66 & \multirow{2}{*}{$\begin{array}{c}1.544 \\
0\end{array}$} & \multirow{2}{*}{\multicolumn{2}{|c|}{.62867}} \\
\hline & $\begin{array}{c}\text { Percentag } \\
\mathrm{e}\end{array}$ & 0 & 0 & $\begin{array}{c}7.2 \\
\%\end{array}$ & $40 \%$ & $52.8 \%$ & & & \\
\hline \multicolumn{7}{|c|}{4 - Learning and Growth Perspective : } & $\begin{array}{r}1.517 \\
0\end{array}$ & & \\
\hline \multirow{2}{*}{$\begin{array}{l}- \\
\text { Employee } \\
\text { s' } \\
\text { satisfactio } \\
\text { n }\end{array}$} & $\begin{array}{c}\text { Frequenc } \\
\text { ies }\end{array}$ & 0 & 0 & 0 & 60 & 65 & \multirow{2}{*}{$\begin{array}{c}1.480 \\
0\end{array}$} & \multirow{2}{*}{.50161} & \\
\hline & $\begin{array}{c}\text { Percentag } \\
\mathrm{e}\end{array}$ & 0 & 0 & 0 & $48 \%$ & $52 \%$ & & & 4 \\
\hline \multirow{2}{*}{$\begin{array}{l}\text {-Training } \\
\text { levels and } \\
\text { time }\end{array}$} & $\begin{array}{c}\text { Frequenc } \\
\text { ies }\end{array}$ & 0 & 0 & 1 & 41 & 83 & \multirow{2}{*}{$\begin{array}{c}1.344 \\
0\end{array}$} & \multirow{2}{*}{.49357} & \\
\hline & $\begin{array}{c}\text { Percentag } \\
\mathrm{e}\end{array}$ & 0 & 0 & $\begin{array}{c}0.8 \\
\%\end{array}$ & $\begin{array}{c}32.8 \\
\%\end{array}$ & $66.4 \%$ & & & \\
\hline \multirow[t]{2}{*}{$\begin{array}{l}\text { Compensa } \\
\text { tion }\end{array}$} & $\begin{array}{c}\text { Frequenc } \\
\text { ies }\end{array}$ & 0 & 0 & 0 & 79 & 46 & \multirow{2}{*}{$\begin{array}{c}1.632 \\
0\end{array}$} & \multirow{2}{*}{.48420} & \\
\hline & $\begin{array}{c}\text { Percentag } \\
\mathrm{e}\end{array}$ & 0 & 0 & 0 & $\begin{array}{c}63.2 \\
\%\end{array}$ & $36.8 \%$ & & & \\
\hline \multirow{2}{*}{$\begin{array}{l}- \\
\text { Employee } \\
\text { s' job } \\
\text { aptitude }\end{array}$} & $\begin{array}{c}\text { Frequenc } \\
\text { ies }\end{array}$ & 0 & 0 & 0 & 57 & 68 & \multirow{2}{*}{$\begin{array}{c}1.456 \\
0\end{array}$} & \multirow{2}{*}{.50006} & \\
\hline & $\begin{array}{c}\text { Percentag } \\
\text { e }\end{array}$ & 0 & 0 & 0 & $\begin{array}{c}45.6 \\
\%\end{array}$ & $54.4 \%$ & & & \\
\hline - & $\begin{array}{c}\text { Frequenc } \\
\text { ies }\end{array}$ & 0 & 0 & 0 & 82 & 43 & $\begin{array}{c}1.656 \\
0\end{array}$ & .47695 & \\
\hline
\end{tabular}




\begin{tabular}{|c|c|c|c|c|c|c|c|c|}
\hline $\begin{array}{l}\mathrm{s}^{\prime} \\
\text { retention }\end{array}$ & $\begin{array}{c}\text { Percentag } \\
\text { e }\end{array}$ & 0 & 0 & 0 & $\begin{array}{c}65.6 \\
\%\end{array}$ & $34.4 \%$ & & \\
\hline \multirow[t]{2}{*}{$\begin{array}{l}\text {-Union } \\
\text { relation }\end{array}$} & $\begin{array}{c}\text { Frequenc } \\
\text { ies }\end{array}$ & 0 & 0 & 0 & 71 & 54 & \multirow{2}{*}{$\begin{array}{c}1.568 \\
0\end{array}$} & \multirow{2}{*}{.49735} \\
\hline & $\begin{array}{c}\text { Percentag } \\
\mathrm{e}\end{array}$ & 0 & 0 & 0 & $\begin{array}{c}56.8 \\
\%\end{array}$ & $43.2 \%$ & & \\
\hline \multirow{2}{*}{$\begin{array}{l}\text { Manageri } \\
\text { al } \\
\text { leadership }\end{array}$} & $\begin{array}{l}\text { Frequenc } \\
\text { ies }\end{array}$ & 0 & 0 & 4 & 47 & 74 & \multirow{2}{*}{$\begin{array}{c}1.440 \\
0\end{array}$} & \multirow{2}{*}{.55938} \\
\hline & $\begin{array}{c}\text { Percentag } \\
\text { e }\end{array}$ & 0 & 0 & $\begin{array}{c}3.2 \\
\%\end{array}$ & $\begin{array}{c}37.6 \\
\%\end{array}$ & $59.2 \%$ & & \\
\hline \multirow{2}{*}{$\begin{array}{l}\text { - Control } \\
\text { of staff } \\
\text { turnover }\end{array}$} & $\begin{array}{c}\text { Frequenc } \\
\text { ies }\end{array}$ & 0 & 0 & 0 & 70 & 55 & \multirow{2}{*}{$\begin{array}{c}1.560 \\
0\end{array}$} & \multirow{2}{*}{.49838} \\
\hline & $\begin{array}{c}\text { Percentag } \\
\text { e }\end{array}$ & 0 & 0 & 0 & $56 \%$ & $44 \%$ & & \\
\hline
\end{tabular}

In Table 11, respondents have been asked to rate and identify the importance of each item in each of the four perspectives in the BSC when evaluating a hotel's performance using a 5-point Likert scale (5 being the most important). The results of the study indicates that the customer dimension is the strongest among other drivers when evaluating a hotel's performance with the highest mean (4.6232), then financial dimension with the mean (4.5964), which indicates that hotels managements have started to pay more attention to other drivers (the customer) than the financial dimension, and they have found out that it is hard to measure performance when it only counts financial aspects due to the uniqueness of hotel products and services. On the other hand, internal business is at the third rank with the mean (1.5400), followed by learning and Growth perspective with the mean (1.5170).

Moreover, the results clarify the core attributes among the four perspectives in the BSC model (one for each perspective in the BSC): ROI in financial, customer satisfaction in customer, occupancy rate in internal business process, and employees' retention in learning and growth.

Furthermore, the study shows that top managements pay attention to financial goals, while heads of units and departments tend to be more focused on non-financial than on financial objectives. The results makes sense since department managers are faced with non-financial issues (customers' complaints, fluctuations of staff and quality of services) on a daily basis, while financial questions are more remote to them; and they appreciate that the importance of intangible assets is higher than that of the traditional physical assets .

\section{Conclusion}

Nowadays hotel organizations operate and compete in a very dynamic environment. Therefore, it becomes necessary to add more value to the business through initiatives that incorporate changes in the way of performing the work, changes in processes, and adequacy of skills. These initiatives should be increasingly strategic to ensure alignment with the organization's goals. In order to achieve the expected results it is necessary to continually improve, so that they remain appropriate and aligned with the organization's strategy measurement systems. A growing number of hotel organizations have been using performance measurement tools. However, due to the recent advances in performance measurement, hotels' managers have constantly looked for a new effective measurement system to evaluate hotels' performance. Since previous performance measures have focused on financial factors, they do not include other important non-financial areas that need to be addressed. Hotels managements find that it is hard to measure actual performance when it only counts financial aspects due 
to the uniqueness of hotel products and services. The BSC model overcomes some of the problems associated with traditional performance measures. It emphasizes the importance of balancing among the four areas: financial, customer, internal business process, and learning and growth perspectives. Furthermore, the BSC integrates the organization's strategic objectives across these four perspectives. This study offers several useful insights into the importance of the BSC model which includes clarifying and updating strategy, communicating strategy throughout the hotel, aligning individual goals with strategy, linking strategic objectives to long-term targets and annual budget, identifying and aligning strategic initiatives, and conducting periodic performance reviews to learn about and improve strategy.

Moreover, this study aimed at identifying the effects of the implementation of the Balanced Scorecard on the hospitality organizations, such as hotels, with a good performance measurement system that tends to achieve better performance and competitive advantage.

Finally, the ability to react to the dynamic business environment, interconnected with the necessary internal changes, is a challenge that calls for a particular attention, and deserves more attention in a performance management tool. Moreover, competitive factors associated with innovation and knowledge is now a challenge in the current business climate. The frameworks that ignore this new reality may compromise the sustainable future of the organizations.

The study recommends that it is necessary to deploy the concept of the Balanced Scorecard through scientific conferences, seminars, and training courses. Moreover, hotels' managers need to capture the new reality about the importance of the intangible assets for adding value in measuring performance. Also, special attention must be placed on properly deploying the intangible assets inherent in the learning and growth, and internal perspectives.

\section{References}

(1) Phillips, P. (1999) Hotel Performance and competitive advantage: a contingency approach. Journal of Contemporary Hospitality Management, 11(7), 359-365.

(2) Neely, A. (2005) The evolution of performance measurement research: Developments in the last decade and research agenda for the next. International Journal of Operations \& Production Management , 25( 12) , 1264-1277.

(3) Phail, R., Herington, C. and Guilding , C. (2008) Human resource managers' perceptions of the applications and merit of the balanced scorecard in hotels .International Journal of Hospitality Management ,27( 4), 623631.

(4) Atkinson, H. and Brown, J. B. (2001) Rethinking performance measures: assessing progress in UK hotels. International Journal of Contemporary Hospitality Management, 13(3), 128-135.

(5) Sainaghi, R.; Phillips, P. and Corti , V. (2013) Measuring hotel performance: Using a balanced scorecard perspectives' approach. International Journal of Hospitality Management, 34, 150- 159.

(6) Evans, N. (2005) Assessing the balanced scorecard as a management tool for hotels. International Journal of Contemporary Hospitality Management, 17 (5), 376- 390.

(7) Phillips, P. and Louvieris, P.(2005) Performance Measurement Systems in Tourism, Hospitality, and Leisure Small Medium-Sized Enterprises: A Balanced Scorecard Perspective. Journal of Travel Research, 44 (2),201211.

( 8 ) Brown, J.B. and McDonnell, B. (1995) The balanced score-card: short-term guest or long-term resident?. International Journal of Contemporary Hospitality Management, 7 (2-3), 7-11.

(9) Kala, D. (2012) Perceived key performance indicators and Balanced Scorecard model for hospitality industry: A conceptual framework Academicia : An International Multidisciplinary Research Journal, South Asian Academic Research Journals,2(5),103- 121.

(10) De Geuser, F.; Mooraj, S. and Oyon, D. (2009) Does the Balanced Scorecard Add Value? Empirical Evidence on its Effect on Performance, European Accounting Review, 18 (1), 93-122.

(11) Doran, M.S., Haddad , K. and Chow, C.W.(2002) Maximizing the Success of Balanced Scorecard Implementation in the Hospitality Industry. International Journal of Hospitality and Tourism Administration, 3 (3), 33-58. 
(12) Borza, A. and Bordean, O.( 2006 ) performance Measuring of tourism small medium-sized enterprises. Management \& Marketing journal, 1 (4), 105-110.

(13) Neely, A.D. (1999) The Performance Measurement Revolution: Why Now and Where Next. International Journal of Operations and Production Management, 19 (2), 205-228.

(14) Harbour, J.L. (1997) The Basics of Performance Measurement. Quality Resources, New York, NY.

(15) Neely, A.D., Gregory, M.J. and Platts, K.W. (1995) Performance Measurement System Design: A Literature Review and Research Agenda. International Journal of Operations and Production Management, 15 (4) , 80-116.

(16) Neely, A., Adams, C., and Kennerley, K. (2002) The performance prism: the scorecard for measuring and managing business success. London: Financial Times Prentice Hall.

(17)Moulin, M. (2004) Eight essentials of performance measurement, International Journal of Health Care Quality Assurance, 17 (3), 110-112.

(18) Quintano, A. (2010) Performance Evaluation in the hospitality industry: The Balanced Scorecard and beyond, Available at:

www.readbag.com/icabr-fullpapers-quintano-alfred (Access on20/11/2014).

( 19 ) Flagstad, E. (2013) The Use of the Balanced Scorecard in Project Management, A Thesis for the degree of Master of Arts in Management, The College of St. Scholastic, Duluth, MN.

( 20 ) Armstrong, M. and Baron, A. (2004) Managing performance: performance management in action.

London: Chartered Institute of Personnel and Development.

(21) Wadongo, B., Edwin, O. and Oscar, K. (2010) Managerial roles and choice of performance measures in the Kenyan five-star hotels using a cross-sectional correlational design. Managing Leisure, 15 (1), 17-31.

( 22) Gomes, J. and Romão , M. ( 2014 ) Advantages and limitations of Performance Measurement Tools : The Balanced Scorecard, Conference: IADIS Information Systems, Available at: www.researchgate.net/publication/260479716_ADVANTAGES_AND (Access on18/10/2014).

(23) Atkinson , A ., Waterhouse, J. and Wells, R .(1997) A Stakeholder Approach to Strategic Performance Measurement . Sloan Management Review, 38(3), 25-28.

(24) Ivankovič, G. ; Janković,S. and. Peršić. M (2010) Framework for Performance Measurement in hospitality industry - Case study Slovenia . Ekonomska istraživanja, Economic research journal, 23(3), 12-23.

(25) The KPI Institute (2014) Balanced Scorecard Review, Available at: www.http// .balancedscorecardreview.com/ (13/11/2014)

(26) Kaplan, R.S. and Norton, D.P. (1992) The Balanced Scorecard - Measures that Drive Performance. Harvard Business Review , 70(1), 71-79.

(27) Balanced Scorecard Collaborative (2010) Learning Centre Section, FAQs and Glossary, available at: https://www.bscol.com/bsc_online/learning/faqs/index.cfm?id=D84E0D4C-BDC5-11D4-

A8C400508BDC96C1. (13/11/2014)

(28) Balanced Scorecard Institute (2010), Balanced Scorecard Basics , Available

at: http://www.balancedscorecard.org/bscresources/aboutthebalancedscorecard/tabid/55/default.aspx. (

$13 / 11 / 2014)$

(29) Eab group (2010) Performance Management - Balanced Scorecard, Available

at: http://www.eabgroup.com.au/en/section/performance-management/balanced-scorecard-i18.html. (

$13 / 11 / 2014)$.

(30) Hotel mule (2010) Performance measurement in the international hospitality industry, Available at: www.http// hotelmule.com/html/83/n-2683-6.html ( 13/11/2014)

(31) Erbasi, A. and Parlakkaya, R. (2012) THE USE OF ANALYTIC HIERARCHY PROCESS IN THE BALANCED SCORECARD: An Approach in a Hotel Firm. Business and Management Review, 2(2), 23 - 37.

(32) Giannopoulos, G. , Holt , A. , Khansalar, E. and Cleanthous, S. (2013) The Use of the Balanced Scorecard in Small Companies. International Journal of Business and Management, 8(14).

(33) Subramaniam, A. (2009) implementing balance scorecard: Balanced Scorecard Airline \& FMCG Implementation, Available at:

http://www.slideshare.net/anandsubramaniam/Implementing-Balance-Scorecard, (Access on 13/11/2014) 
(34) Kim, W., G. and Lee, S. (2007) Developing a new hotel performance measurement system: application of the Balanced Scorecard and Fuzzy Analytic Hierarchy Process Model, Proceedings of the First Hospitality and Leisure: Business advances and applied research conference, Lausanne, Switzerland.89-97.

(35) Niven, P. R. (2008) Balanced Scorecard Step-by-Step-for government and nonprofit agencies, Second Edition, New York, John Wiley\& Sons.

(36) Kaplan R.S., Norton D.P. (2004) Strategy Maps: converting intangible assets into tangible outcomes. Harvard Business School Press.

(37) Bento, Al. ; Bento, R. and White, L. F. (2013) Validating Cause-and-Effect Relationships in the Balanced Scorecard. Academy of Accounting and Financial Studies Journal , 17,(3).

(38) Banker, R.D. ; Chang ,H. and Pizzini, M. (2011) The judgmental effects of strategy maps in balanced scorecard performance evaluations. International Journal of Accounting Information Systems ,12, 259-279.

(39) Chiung , J.L. (2006) A Dynamic Connection of Balanced Scorecard Applied for the Hotel . Journal of Services Research, 6 (2) .

(40) Kaplan, R. and Norton, D.(1996) Using the Balanced Scorecard as a Strategic Management System. Harvard Business Review 74 (1), 75-85.

(41) Denton ,G.A. and White , B. ( 2000 ) Implementing a balanced-scorecard approach to managing hotel operations: The case of White Lodging Services. The Cornell Hotel and Restaurant Administration Quarterly, 41(1), 94-107.

(42) McWhorter , L. (2001) ) The Balanced Scorecard: AN Empirical analysis of its effect ON managers' job satisfaction and performance evaluations, A Thesis for the degree of Doctor of Philosophy, University of Kentucky.

(43) Caudle, S. (2008) The Balanced Scorecard: A Strategic Tool in Implementing Homeland Security Strategies . Homeland Security Affairs journal of the Naval Postgraduate School Center for Homeland Defense and Security, 3.

(44) Lipe , M.G. and Salterio, S.E.(2000) The Balanced Scorecard: Judgment Effects of Common and Unique performance measures, The Accounting review , 75 (3), 283-298.

(45)Bowen, R. (2011) Weighing the Pros and Cons of Balanced Scorecards, Available at , www.http// C:/Users/ghada/Desktop/BSC/Advantages\%20\&\%20Disadvantages\%20of\%20Balanced\%20Scorecard\%20Usag e\%20Do\%20They\%20Really\%20Make\%20a\%20Difference.htm\#sthash.vsNLwNkL.dpuf ， ( Access on $12 / 08 / 2014)$.

(46) Christesen, D. (2008) The Impact of Balanced Scorecard Usage on Organization Performance, A Thesis for the Degree of Doctor of philosophy, The university of Minnesota.

(47) Cheangtawee,P.; Praneetpolgrang, P. and Paopun, N .(2005) An Evaluation E-Commerce Performance in Hotel Businesses Using Balanced Scorecard, Proceedings of the Fifth International Conference on Electronic Business, Hong Kong, December 5-9,296 - 298.

(48) Mackay A. (2004) A Practitioners' Report Based on: 'Shareholder and Stakeholder Approaches to Strategic Performance Measurement Using the Balanced Scorecard', The Chartered Institute of Management Accountants ( CIMA)

(49) Qin , S. Y. ; Atkins, A.S. and H. Yu, H. (2013) Balanced Scorecard Approach to Evaluate Business Performance Measurement Using Web Tools in E-Tourism. International Journal of Computing Science and Communication Technologies, 5 (2),822-828.

(50) Baierl , R. and Steinhauser ,C. (2014) The Strategic hospitality Scorecard: Developing an Innovative Framework for the hospitality industry. Journal of tourism research , 8.

(51) Niven, P. R. (2003) Balanced Scorecard Step-by-Step - Maximizing performance and maintaining results . New York, John Wiley\& Sons.

(52) Atkinson, H. (2006) Strategy implementation: a role for the balanced scorecard?. Management Decisions, 44(10),1441-1460.

(53) Al-Tawail Management Consulting \& Training (2009) Balanced scorecard, Available at , www.http// altawail.com.clearwebstats.com ( Access on 20/11/2014 ) .

(54) Kennerly, M., and Neely, A. (2000) Performance management frameworks: a review. proceedings, 2n International conference on performance management,

Cambridge, U. K., 291-298. 
(55) Kanji, G. (2002) Performance measurement system. Total Quality Management, 13(5), 715-728.

(56) Kenneth, K. (2010) The Use of Balanced Scorecard Measures in Executive Incentives and Organizational Performance, , A Thesis for the degree of Doctor of Philosophy, Carleton University, Ottawa, Canada.

(57) Kaskey, V. (2008) The Balanced Scorecard: A Comparative study of accounting education and experience on common measure bias and trust in a Balanced Scorecard, A Thesis for the Degree of Doctor of Philosophy , Capella University

(58) Tucker, S.(2006) The Balanced Scorecard and long-term profitability, A Thesis for the Degree of Master of Business Administration In the Graduate Academic Unit of Administration, The University of New Brunswick.

\author{
استخدام نموذج بطاقة الأداء المتوازن لتقييم الأداء بمؤسسات الضيافة \\ غادة محمد خيرت عبد الحميد \\ قسم الدر اسات السياحية ـ كلية السياحة و الفنادق - جامعة مدينة السادات
}

\title{
الملخص العربي
}

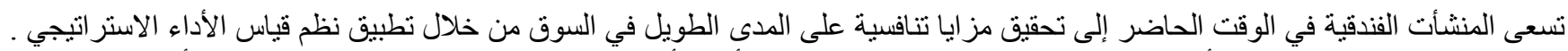

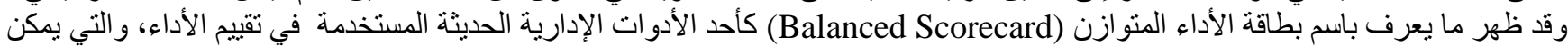

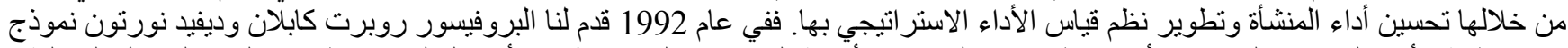

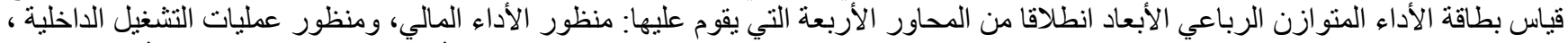

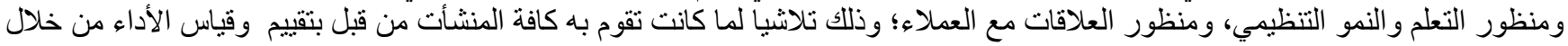

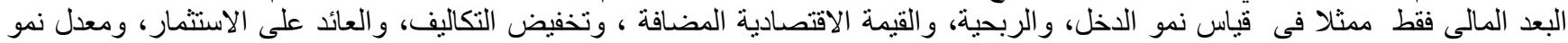

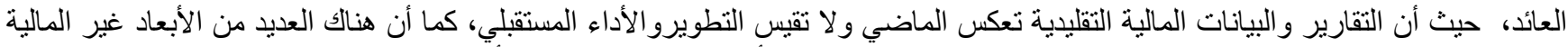

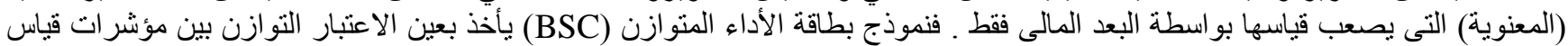

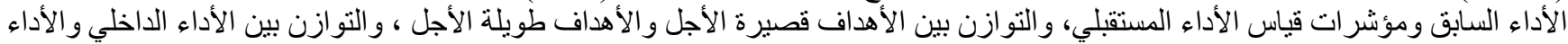

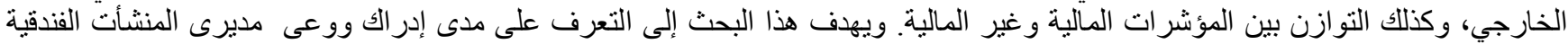

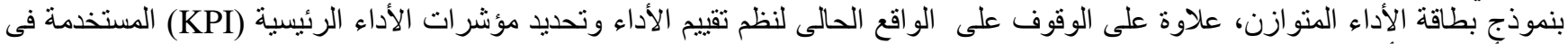

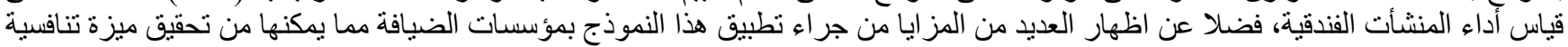

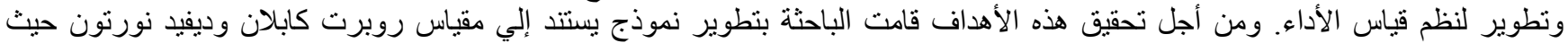

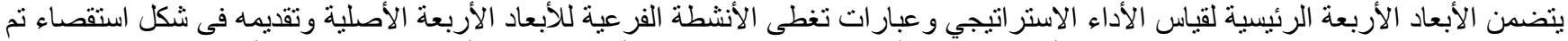

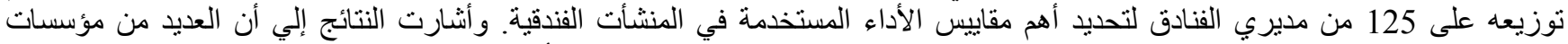

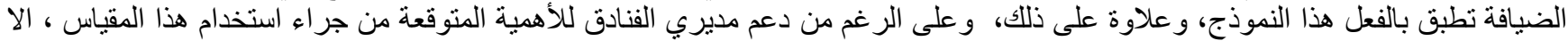

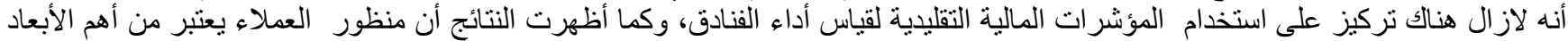

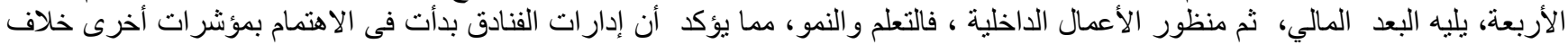
المؤشر ات المالية نتيجة تميز المنتجات و الخدمات الفندقية. 